\title{
Actual problems in food supplying to the world's population
}

The purpose of the article is to investigate the problem of food shortages for a significant number of the population worldwide, taking into account the history of the problem, its causes, consequences, statistics and prospects for solving in accordance with existing trends.

Research methods. Methods used: theoretical generalization - for characterizing international organizations and program goals that work to combat hunger, analysis and synthesis - for consideration the dynamics number of starving people on the planet and identify regions and countries with largest expanding such problem, comparative evaluation - for comparing absolute and relative statistical indicators in various aspects of the problem, historical - for structuring over time the measures taken to ensure sufficient food supply and their actual results, graphic - for better visualization the comparative statistics.

Research results. Information on the responsible institutions that settle food shortages around the world is provided, key issues that need attention in the context of food insecurity are described, quantitative indicators of the global food problem are considered, the uneven nature of its distribution is highlighted, given list of the factors that deepen social and economic problems for the population, a clear link between poverty and chronic malnutrition is determined, critical remarks about the reality of prospect to overcome hunger according to the planned schedule are formed.

Scientific novelty. An assessment of development the situation with the number of starving people in the world in the coming decades is made, taking into account an expected demographic changes and potential resources of agricultural production as a key sector in this problem.

Practical significance. The provisions of the article are aimed at underlining weaknesses in the global food security system, detailing them and presenting to domestic authorities and business structures in order to find a balance between expanding export potential, participating in international initiatives and maintaining economical-effective agricultural sector. Figs.: 1. Refs.: 17

Keywords: food; hunger; problem; poverty; UN; global goal.

Dukhnytskyi Bohdan Volodymyrovych - candidate of economic sciences, senior research fellow of the department of agrarian production economics and international integration, National Scientific Centre "Institute of Agrarian Economics" (10, Heroiv Oborony St., Kyiv, 03127)

E-mail: duhnitsky@faust.kiev.ua

ORCID iD https://orcid.org/0000-0002-5521-5602

Scientific problem. The modern world demonstrates significant progress in scientific and technological development, which is constantly accelerating. Mankind needs much shorter periods of time to reach the next milestone on the path to overall progress. Such patterns are observed in many spheres of life, contributing to their optimization and maximum efficiency. Economic activities, in particular those related to the production and processing of agricultural products, have not been left out of these processes. Along with the growth of purely quantitative indicators in this sector, there is a significant diversification of goods and services that it is able to offer. Agrifood market not only reflects the existing achievements in its daily activities, but also uses new aspects of its own potential.

At the same time, the problem of adequate and timely food supply for many millions of

(c) B.V. Dukhnytskyi, 2020 people still remains unresolved worldwide. Experience has shown that the usual increase in the physical volume of food production is clearly not enough. Taken measures do not give the desired result, because the number of starving people is consistently high. The situation is complicated by fact that this has been caused by a whole range of reasons that cannot be solved at once, and therefore need a structural and coordinated solution. Currently, the world community continues to look for optimal ways to eliminate this problem, combining political, economic, social and scientific mechanisms.

Analysis of recent research and publications. The current state of food security in the world and in Ukraine is covered in the publications of Ukrainian scientists, such as Yu.O. Lupenko, M.I. Pugachov [9], O.G. Bilorus, P.T. Sabluk, V.I. Vlasov [1], M.P. Sychevsky [8] and others. Analytical and statistical data on this issue are regularly pro- 
vided by many specialized organizations in Ukraine [7] and abroad [10, 12 - 17].

The purpose of the article is to investigate the problem of food shortages for a significant number of the population worldwide, taking into account the history of the problem, its causes, consequences, statistics and prospects for solving in accordance with existing trends.

Research methodology. History of emergence the global goals to combat hunger at the United Nations level is traced through the adopted policy documents. The necessary indicators to achieve the planned goal are considered separately. Total activities of FAO as a key organization in the development of agriculture and food supply are described. Current statistics on the number of starving people in the world, its regions and separate countries are taken from the report «The State of Food Security and Nutrition in the World - 2019». Rate of reduction the number of starving people is compared with the desired final indicator to demonstrate the existing difference. In addition, the relation between hunger and poverty according to the World Bank's definition and existing data is shown, as well as forecasts of population growth in the coming decades. Taking into account the above, the most available ways to solve the food problem at this stage are proposed.

Research results. Food for each person is the first of all a basic needs that allows to maintain own organism at sufficient level for stable functioning. Therefore, the sufficience and accessibility of food is always under priority, and ensuring the continuity of their production plays a crucial role. The situation becomes really threatening when it changes the scale from individual to mass, requiring urgent concerted collective action to eliminate it.

The problem of food security or malnutrition is solved not only by each state, but also at the international community level. If the country's authorities are able to resolve this issue or it is temporary, then there is no prospect for the problem to become permanent. However, in modern conditions, the scale of various malnutrition types indicates the global nature of this phenomenon, which has not been resolved for decades, and the most vulnerable countries continue to suffer more severely from it.
For the first time, the task of liquidating hunger at the highest level was set in the UN Millennium Declaration, signed in 2000, which stated that the goal was to halve the proportion of the world's starving population between 1990 and 2015. The vast majority was living, as for today, in developing countries. Thus, in the early 1990s, the number of hungry people in such countries exceeded 990 million, which was more than $23 \%$ of their population. At the end of the deadline (2015), the corresponding figures for developing countries and regions reached 780 million people and almost $13 \%$, thus there was significant progress in meeting the task of combating hunger. At the same time, experts pay attention to many factors that always significantly complicate the situation with adequate food security, including economic crises, political situation, natural disasters, price instability on the markets of raw materials and energy resources [10].

In the autumn of 2015, the United Nations approved new «Sustainable Development Goals» (SDG) for the next 15 years (20162030). If the previous goals focused mainly on the needs of developing countries, then «Sustainable Development Goals» should be applied to all countries without exception, taking into account their capabilities, existing conditions and national priorities. A total of 17 goals are envisaged, including № 2 «Zero hunger», which includes food security, improving nutrition and promoting sustainable agricultural development. Its main result should be the complete overcoming of hunger and all forms of malnutrition [13].

To achieve this goal, the UN has identified a number of necessary tasks, including: 1 . Overcome hunger by 2030 and ensure safe, nutritious and adequate food for all, especially the most vulnerable people, throughout the year.

2. By 2030 eliminate all forms of malnutrition, including by 2025 achieving the targets concerning depletion of little children, ensuring proper nutrition of pregnant women and elderly people.

3. By 2030 to double the productivity of agriculture and the income of small food producers, including women, indigenous peoples, family farms, while striving for equal access to productive resources and expanding opportunities for more value-added products.

4. By 2030 provide the creation of stable food production systems, implementing effec- 
tive methods in agriculture that allow to preserve ecosystems, adapt to climate change, improve soil quality [13].

5. By 2020 provide support for the genetic diversity of agricultural plants, seeds, domestic animals at the national, regional and international levels.

6. Increase investment in rural infrastructure, agricultural research and promotion, technology development to strengthen production potential, especially in the least developed countries.

7. Do not allow restrictions on trade in world agricultural markets, including through the abolition of all forms of export subsidies.

8. Take measures for the proper functioning of food markets by facilitating access to information on their functioning, in particular on food reserves with purpose to limit price volatility [13].

Our country has not stayed away from these important global initiatives. In 2017, the government presented National Report "Sustainable Development Goals: Ukraine», which contains an adapted version of 17 global SDG, taking into account specific indicators to achieve them [4]. In particular, Goal 2 is entitled «Overcoming hunger, agricultural development» and includes 4 tasks: 1). to provide the availability of a balanced diet at scientific standard level for all segments of the population; 2). to double the productivity of agriculture, primarily through the use of innovative technologies; 3 ). to provide the creation of sustainable food production systems that contribute to preservation of ecosystems and gradually improve the quality of land and soils, primarily through the use of innovative technologies; 4). to reduce food price volatility. To accomplish the first task, target indicators have been developed that forecast an increase in annual consumption of meat, milk and fruit per capita, so that by 2030 it will reach a scientific level [4].

In addition, on September 30, 2019, Decree of the President of Ukraine № 722/2019 «On Sustainable Development Goals of Ukraine until 2030" came into force, which provides following the declared goals, their monitoring and recommendations to relevant academies of sciences, including NAAS, to take into account the SDG of Ukraine when determining the priority areas of research [6].

The UN has a specially created Food and Agriculture Organization (FAO) in its struc- ture, which deals with food security, rural development and agricultural production. It was established in 1945. FAO now operates in more than 130 countries and has almost 200 members. Since 1963, it has been working with the United Nations to manage the World Food Programme (WFP), whose main function is to provide food aid, fight hunger and poverty in developing countries. It is estimated that each year the World Food Program provides food to approximately 100 million people worldwide [12, 17].

In addition to being responsible for the Sustainable Development Goal № 2, FAO is involved in other goals, related with social, economic and environmental aspects, including responsible consumption and production, saving of marine and terrestrial ecosystems, use of clean water and promotion the sanitation, stimulation of gender equality.

Based on the fact that many countries are constantly facing problems in the agricultural development, to help them FAO has identified five priority areas, around which the main professional work of this organization is concentrated [12].

Assistance in combating hunger, food insecurity and malnutrition. In partnership with governments and other organizations, FAO is trying to resolve the problem of malnutrition, which is accompanied by a lack of food and the growing number of overweight people and nutrient deficit in the daily diet.

Improving productivity and stability of agriculture, forestry and fisheries. Given the expected growth of the world's population by 2050, the pressure on agricultural production will increase significantly, so there will be a need to produce more food with fewer resources. It is proposed to review the existing policy in this direction by introducing a common vision of sustainable agricultural development in the practice of all interested countries.

Poverty reduction in rural areas. Because hunger, first of all, serves as a clear indicator of poverty of the population living mainly in rural areas, therefore, the simultaneous declining of hunger and poverty by 2030 is becoming critical and a priority for the Sustainable Development Goals.

Ensuring the inclusiveness and efficiency of agri-food systems. With the development of globalization, agriculture is gradually losing its independence, becoming more integrated into intersectoral production and marketing 
chains. This makes it much more difficult for small farmers to participate and be involved in such processes, so they need to be better informed and adapted to the nuances of current situation on international food market.

Increasing the resilience of livelihoods to threats and crises. The main causes of food problems and hunger are military conflicts, natural disasters and economic crises. The vast majority of people who suffer from these causes belong to rural families, whose survival depends on agriculture. Therefore, FAO provides humanitarian assistance, contributes to the achievement and maintenance of sustainable peace, conducts a comprehensive assessment of risk prevention and ways to avoid them at the global, national and local levels [12].

Despite the achieved indicators and the continuation of international policy in the field of combating hunger, the modern situation is showing signs of deterioration now. In 2015, the number of malnourished people was 785 mil- lion, in 2016 - 797 million, in 2017 - 812 million, and in 2018 - almost 822 million people. This is evidenced by the latest data from the Food and Agriculture Organization of the United Nations, published in the report «The State of Food Security and Nutrition in the World - 2019». Asia is the region where the most people suffer from food shortages. According to the average data of 2016-2018, the number of starving people in Asian countries was 513 million. Next in this disappointing ranking is Africa (246 million), along with Latin America and the Caribbean (about 42 million). At the same time, the share of those who are constantly malnourished in Africa $(19,6 \%)$ is much higher than in other regions, while in Asia this figure is $11,4 \%$, and in the world as a whole - 10,8\% [16]. In absolute terms, the countries with the largest number of starving people are India and China, with a total population of more than 300 million, and the rest of the list is also situated in Asia and Africa (Figure).

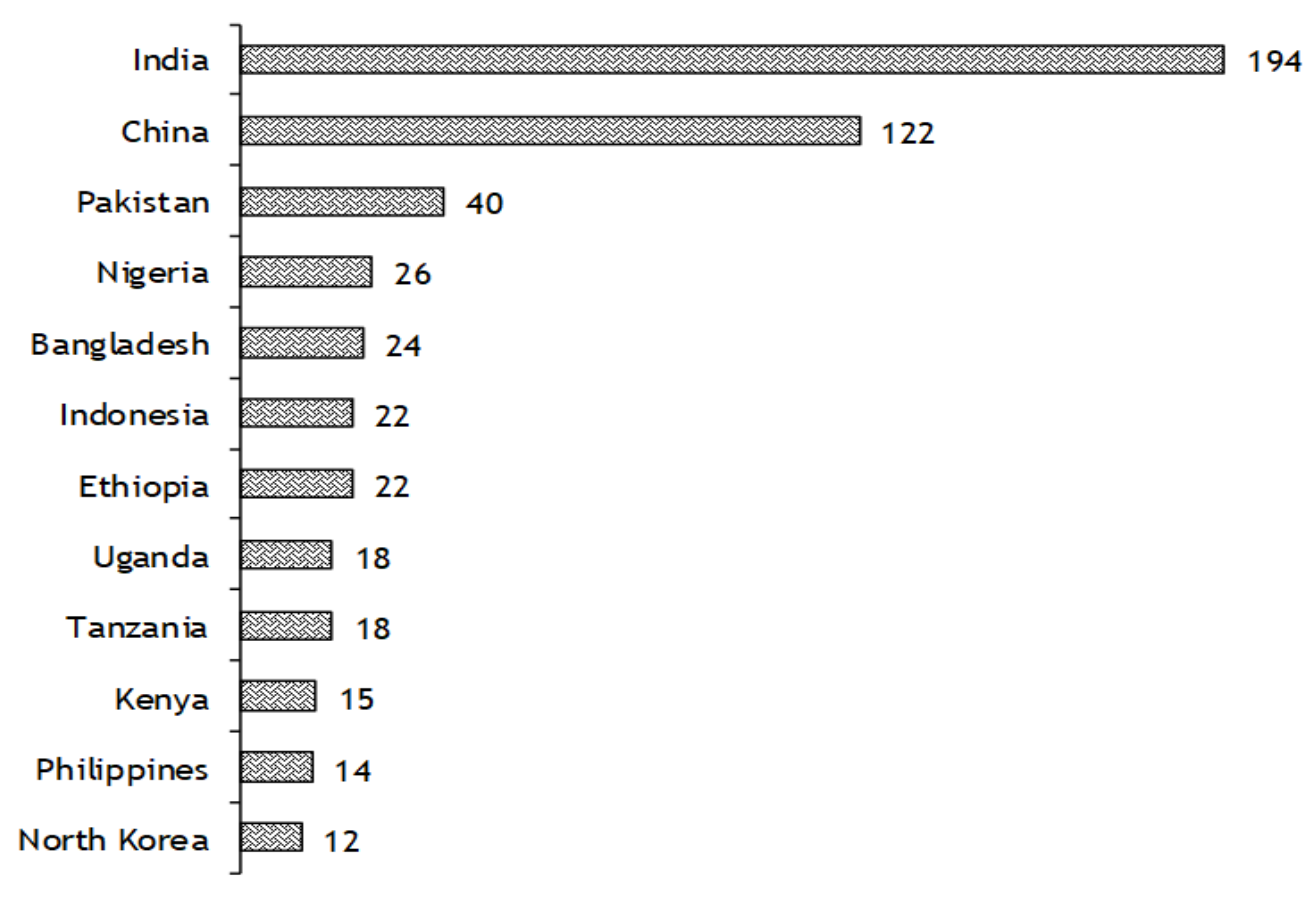

Figure. Countries with the largest number of undernourished people, million

Source: Formed by author based on [16].

Therefore, fulfillment of the goal concerning eliminating the hunger by 2030 is under a big uncertainty, because there are only 10 years left before the deadline date, and it is needed to correct the negative dynamics that has emerged from the very beginning of the set term. In fact, for today, in 20 years of fighting against hunger, the number of people suffering from chronic malnutrition has declined by about 200 million. Thus, in order to fully achieving the goal, international community will have to accelerate several times the rate of reduction number of hungry people, which in the terms of expected crisis in the global economy seems almost unrealistic. On the contrary, there are more and more predictions that the number of socially vulnerable people will increase in the near future.

The close relation between human poverty and hunger demonstrates the poverty line. By 
definition, the poverty line is the level of income below which a person is considered poor. Since 2015, the World Bank has updated the international poverty line to $\$ 1,90$ per day at purchasing power parity. According to its estimations, in 2015, 737 million people lived below the poverty line in the world, mostly in Asia and Africa. And the UN Human Development Report 2019 states that in developing countries more than $14 \%$ of the population lives below the poverty line, meaning less than $\$ 1,90$ per day $[3,14]$. As we can see, in absolute and relative numbers there is a significant similarity between the quantity and percentage of hungry people and the quantity and percentage of people below the poverty line, particularly in developed countries. It should be taken in mind that many people's incomes are not much above the poverty line, so they are also more likely to suffer from food insecurity.

Moreover, the United Nations estimates that the world's population will increase by 2 billion to 9,7 billion by 2050 [2]. It is clear that more food will have to be produced to meet this growing demand. It is difficult to forecast accurately the required production volumes, but they should be approximately $30 \%$ larger. Taking into account that now about $4 / 5$ of the world's population lives in developing countries, the most share of growth will concern them. At the same time, the problem of combating hunger becomes even more relevant, because of states that do not have economic stability can not overcome it yet, even though received foreign aid.

However, even in such ambiguous conditions and forecasts, there are reserves to overcome hunger $[1,7,8,9,11,15]$. First of all, even the actual capacities of agricultural production and food industry can feed all mankind. The difficulty lies in their uneven distribution, so some countries and territories have a surplus of food, and the rest are short of food, sometimes too strong. Land, freshwater reserves, and the planet's biodiversity are rapidly deplet-

\section{Список бібліографічних посилань}

1. Глобальна продовольча безпека / Білорус О. Г., Зубець М. В., Саблук П. Т., Власов В. І. Київ : ННЦ ІАЕ, 2009. $486 \mathrm{c}$.

2. До 2050 року населення Землі сягне 9,7 мільярда OOH. URL : https://www.ukrinform.ua/rubric-culture/2723333do-2050-roku-naselenna-zemli-sagne-97-milarda-oon.html.

3. Межа бідності. URL : https://uk.wikipedia.org/wiki/ Межа_бідності.

4. Національна доповідь «Цілі сталого розвитку: Україна». URL : http://www.un.org.ua/images/SDGs_NationalReportUA_Web_1.pdf. ing and degrading, especially due to human activities and climate change. There is also an irrational use of food. According to the UN, a third of the world's food is wasted, banally purchased in excess, not consumed in time or simply spoiled [5]. Therefore, humanity is quite capable to overcome the food problem in a current scales, but this requires more resources, awareness the seriousness of situation, changing approaches to agriculture and unite efforts of other countries and institutions within a common system.

Conclusions. One of the most significant problems of mankind remains the high number of starving people around the world. According to statistics, every ninth inhabitant of our planet suffers from regular malnutrition. The goal of reducing and eliminating quantitative indicators of this occurrence has been set twice at the highest level, but has not yet been fully resolved. The fight against hunger is complicated by a number of typical reasons that characterize economic and social situation in developing countries, additionally leveling the achievements of previous few years. The number of undernourished people has been growing since 2015, and the expected effects of global financial crisis and consequences of the coronavirus pandemic in the near future will hit even more economically vulnerable people. Obviously, that hunger is a direct result of poverty, which has affected about the same number of people. At the current rates of its achieving, this issue may not be resolved at all, although it will continue to be declared. The population of the planet is constantly growing, including in regions suffering from hunger, and this process will lead to an even greater production pressure on agricultural resources. The way out of this situation can be not only to increase the physical volume of food production, but also to balance the correlation between factual and necessary food consumption, review strategic priorities of the global food market, expand information support in the context of obligatory follow.

\section{References}

1. Bilorus, O.G., Zubets, M.V., Sabluk, P.T., Vlasov, V.I. (2009). Globalna prodovolcha bezpeka [Global food security]. Kyiv: NNTs IAE [In Ukrainian].

2. Do 2050 roku naselennia Zemli siagne 9,7 miliarda - OON. [By 2050 the world's population will reach 9,7 billion - the UN]. (2019). Retrieved from: https://www.ukrinform.ua/rubricculture/2723333-do-2050-roku-naselenna-zemli-sagne-97milarda-oon.html [In Ukrainian].

3. Mezha bidnosti. [Poverty line]. (2020). Retrieved from: https://uk.wikipedia.org/wiki/Межа_бідності [In Ukrainian]. 
5. ООН запустила флешмоб, який навчить правильно боротися з харчовими відходами. URL : https://glavcom.ua/ news/oon-zapustila-fleshmob-yakiy-navchit-pravilno-borotisyaz-harchovimi-vidhodami-629967.html.

6. Про Цілі сталого розвитку України на період до 2030 року : Указ Президента України № 722/2019 від 30.09.2019. URL : https://www.president.gov.ua/documents/7222019-29825.

7. Продовольча безпека в Україні у 2018 році. Огляд основних індикаторів. URL : http://edclub.com.ua/analityka/ prodovolcha-bezpeka-v-ukrayini-u-2018-roci-oglyad-osnovnyhindykatoriv.

8. Сичевський М. П. Глобальна продовольча безпека та місце України в її досягненні. Економіка АПК. 2019. № 1. С. 6-17.

9. Формування глобального і регіонального ринків сільськогосподарської сировини та продовольства : монографія / [Ю. О. Лупенко, М. І. Пугачов, Б. В. Духницький та ін.] ; за ред. Ю. О. Лупенка, М. І. Пугачова. Київ : ННЦ «ІAE», 2015. 320 c.

10. Цели развития тысячелетия: доклад за 2015 год. URL : https://www.un.org/ru/millenniumgoals/mdgreport2015.pdf.

11. Blockchain for Agriculture and Food / Brewster C., Ge L., Spek J., Smeenk A., Top J. Wageningen Economic Research REPORT 2017-112. Wageningen. 2017. 38 p.

12. Food and Agriculture Organization. URL : http://www.fao.org/about/en/.

13. Goal 2: Zero Hunger. URL : https://www.un.org/ sustainabledevelopment/hunger/.

14. Human Development Report 2019. URL : http://hdr.undp.org/sites/default/files/hdr2019.pdf.

15. OECD-FAO Agricultural Outlook 2019-2028. URL : http: //www.fao.org/3/ca4076en/ca4076en.pdf.

16. The State of Food Security and Nutrition in the World 2019. URL : http://www.fao.org/3/ca5162en/ca5162en.pdf.

17. World Food Programme. URL : https://www.wfp.org/ overview.
4. Natsionalna dopovid «Tsili stalogo rozvytku: Ukraina». [National Report «Sustainable Development Goals: Ukraine»]. (2017). Retrieved from: http://www.un.org.ua/images/SDGs_ NationalReportUA_Web_1.pdf [In Ukrainian].

5. OON zapustyla fleshmob, yakyi navchyt pravylno borotysia z kharchovymy vidkhodamy. [The UN has launched a flash mob that will teach how to properly deal with food waste] (2019). Retrieved from: https://glavcom.ua/news/oon-zapustilafleshmob-yakiy-navchit-pravilno-borotisya-z-harchovimividhodami-629967.html [In Ukrainian].

6. Pro Tsili stalogo rozvytku Ukrainy na period do 2030 roku: Ukaz Prezydenta Ukrainy \# 722/2019 [On the Sustainable Development Goals of Ukraine until 2030 Decree of the President of Ukraine No. 722/2019]. (2019). Retrieved from: https://www.president.gov.ua/documents/7222019-29825 [In Ukrainian].

7. Prodovolcha bezpeka v Ukraini u 2018 rotsi. Ogliad osnovnykh indykatoriv. [Food security in Ukraine in 2018. Key indicators overview]. (2018). Retrieved from: http://edclub.com.ua/ analityka/prodovolcha-bezpeka-v-ukrayini-u-2018-roci-oglyadosnovnyh-indykatoriv [In Ukrainian].

8. Sychevskiy, M.P. (2019). Globalna prodovolcha bezpeka ta mistse Ukrainy $v$ yii dosiagnenni [Global food security and Ukraine's place in it's achieving]. Ekonomika APK, 1, pp. 6-17 [In Ukrainian].

9. Lupenko, Yu.O., Pugachov, M.I., Dukhnytskyi, B.V., et al. (2015). Formuvannia globalnoho i regionalnogo rynkiv silskogospodarskoi syrovyny ta prodovolstva: monografiia [Formation of global and regional markets for agricultural raw and food: monograph]. Yu.O. Lupenko, M.I. Pugachov (Ed.). Kyiv: NNTs «IAE» [In Ukrainian].

10. Tsely razvytyia tysiacheletyia: doklad za 2015 god. [Millennium Development Goals: 2015 Report]. (2015). Retrieved from: https://www.un.org/ru/millenniumgoals/mdgreport2015.pdf [In Russian].

11. Brewster, C., Ge, L., Smeenk, A., Top, J. (2017). Blockchain for Agriculture and Food. Wageningen Economic Research REPORT 2017-112. Wageningen [In English].

12. Food and Agriculture Organization. (2020). Retrieved from: http: //www.fao.org/about/en/ [In English].

13. Goal 2: Zero Hunger. (2015). Retrieved from: https://www.un.org/sustainabledevelopment/hunger/ [In English].

14. Human Development Report 2019. (2019). Retrieved from: http://hdr.undp.org/sites/default/files/hdr2019.pdf [In English].

15. OECD-FAO Agricultural Outlook 2019-2028. (2019). Retrieved from: http: //www.fao.org/3/ca4076en/ca4076en.pdf [In English].

16. The State of Food Security and Nutrition in the World 2019. (2019). Food and Agriculture Organization of the United Nations. Retrieved from: http://www.fao.org/3/ca5162en/ ca5162en.pdf [In English].

17. World Food Programme. (2020). Retrieved from: https: //www.wfp.org/overview [In English].

\section{Духницький Б.В. Актуальні проблеми забезпечення продовольством населення світу}

Mema cmammi - розглянути питання нестачі продовольства для значної кількості населення на загальносвітовому рівні, враховуючи історію розвитку проблеми, їі причини, наслідки, статистичні показники та перспективи вирішення відповідно до існуючих тенденцій .

Методика дослідження. Використано методи: теоретичного узагальнення - для характеристики міжнародних організацій та програмних цілей, які функціонують для боротьби з голодом; аналізу й синтезу - для розгляду динаміки кількості голодуючих на планеті та виявлення регіонів і країн з найбільшими масштабами проблеми; порівняльної оцінки - для зіставлення абсолютних і відносних статистичних показників у різних аспектах наявної проблеми; історичний - для структурування в часі вжитих заходів стосовно достатнього забезпечення продовольством та їх фактичних результатів; графічний - для повнішої візуалізації порівняльних статистичних даних.

Результати дослідження. Наведено інформацію про відповідальні установи, які вирішують питання нестачі продовольчих ресурсів по всьому світу, охарактеризовано супутні ключові положення, які потребують уваги в контексті поєднання з недостатністю харчів, розглянуто кількісні показники глобальної продовольчої проблеми, виділено нерівномірний характер їі поширення, перераховано фактори, що поглиблюють сочіальні й економічні негаразди для населення, встановлено чіткий зв'язок між бідністю і хронічним недоїданням, сформовано критичні зауваження стосовно реальності перспективи повного подолання голоду згідно із запланованим розкладом.

Елементи наукової новизни. Виконано оцінку розвитку ситуації з кількістю голодуючих у світі в найближчі десятиліття, беручи до уваги очікувані зміни демографічного характеру та потенційні ресурси сільськогосподарського виробництва як ключової галузі в цій проблемі.

Практична значущість. Наведені положення спрямовані на виділення слабких місць у системі глобальної продовольчої безпеки, їх деталізацію та представлення вітчизняним органам влади та бізнес-структурам з метою знаходження ними 
балансу між розширенням експортного потенціалу, участю в міжнародних ініціативах і збереженням економічно ефективної аграрної галузі. Рис.: 1. Бібліогр.: 17.

Ключові слова: продовольство; голод; проблема; бідність; оОН; глобальна ціль.

Духницький Богдан Володимирович - кандидат економічних наук, старший науковий співробітник відділу економіки аграрного виробництва та міжнародної інтеграції, Національний науковий центр «Інститут аграрної економіки» (03127, м. Київ, вул. Героїв Оборони, 10)

E-mail: duhnitsky@faust.kiev.ua

ORCID iD https://orcid.org/0000-0002-5521-5602

\section{Духницкий Б.В. Актуальные проблемы обеспечения продовольствием населения мира}

Цель статьи - рассмотреть вопрос нехватки продовольствия для значительного количества населения на общемировом уровне, учитывая историю развития проблемы, ее причины, последствия, статистические показатели и перспективы решения в соответствии с существующими тенденциями.

Методика исследования. Использованы методы: теоретического обобщения - для характеристики международных организаций и программных целей, которые функционируют для борьбы с голодом; анализа и синтеза - для рассмотрения динамики количества голодающих на планете и выявления регионов и стран с крупнейшими масштабами проблемы; сравнительной оценки - для сопоставления абсолютных и относительных статистических показателей в разных аспектах существующей проблемы; исторический - для структурирования во времени принятых мер по достаточному обеспечению продовольствием и их фактических результатов; графический - для более полной визуализации сравнительных статистических данных.

Результаты исследования. Приведена информация об ответственных учреждениях, которые решают вопрос нехватки продовольственных ресурсов по всему миру, охарактеризованы сопутствующие ключевые положения, которые требуют внимания в контексте сочетания с недостаточностью пищи, рассмотрены количественные показатели глобальной продовольственной проблемы, выделен неравномерный характер её распространения, перечислены факторы, углубляющие социальные и экономические проблемы для населения, установлена четкая связь между бедностью и хроническим недоеданием, сформированы критические замечания относительно реальности перспективы полного преодоления голода согласно запланированному расписанию.

Элементы научной новизны. Выполнена оценка развития ситуации с количеством голодающих в мире в ближайшие десятилетия, принимая во внимание ожидаемые изменения демографического характера и потенциальные ресурсы сельскохозяйственного производства как ключевой отрасли в этой проблеме.

Практическая значимость. Приведенные положения направлены на выделение слабых мест в системе глобальной продовольственной безопасности, их детализацию и представление отечественным органам власти и бизнесструктурам с целью нахождения ими баланса между расширением экспортного потенциала, участием в международных инициативах и сохранением экономически эффективной аграрной отрасли. Илл.: 1. Библиогр.: 17.

Ключевые слова: продовольствие; голод; проблема; бедность; ООН; глобальная цель.

Духницкий Богдан Владимирович - кандидат экономических наук, старший научный сотрудник отдела экономики аграрного производства и международной интеграции, Национальный научный центр «Институт аграрной экономики» (03127, г. Киев, ул. Героев Обороны, 10)

E-mail: duhnitsky@faust.kiev.ua

ORCID iD https://orcid.org/0000-0002-5521-5602

The article has been received 01.06.2020

Revision: 15.06.2020

Бібліографічний опис для цитування:

Dukhnytskyi В. V. Actual problems in food supplying to the world's population. Економіка АПК. 2020. № 6. C. 91 - 97. https://doi.org/10.32317/2221-1055.202006091

Dukhnytskyi, B.V. (2020). Actual problems in food supplying to the world's population. Ekonomika APK, 6, pp. 91 - 97 [In English]. https://doi.org/10.32317/2221-1055.202006091 